\title{
Oil Bunkering in the Niger Delta:
}

\section{A Social Harm Perspective}

\section{Alice Fiennes \\ MSc in Criminology and Criminal Justice}

Nigerian crude oil is said to be 'stolen' on an industrial scale (Katsouris \& Sayne 2013, iii). United Nations' estimates have suggested that Nigeria's shadow oil industry has a turnover of US\$2 billion per year (Burgis 2015, p. 177). Oil theft — known as 'bunkering' — involves tapping into existing infrastructure and extracting oil, either for sale or for local consumption in the oilrich Niger Delta region (Katsouris \& Sayne 2013). Within Nigeria, oil bunkering is theft and can be prosecuted under the 1975 Anti-Sabotage Act or the Petroleum Act, although in practice little successful prosecution has taken place (Naanen 2019).

The perspectives of social harm and received criminological literature both offer useful insight into the practice of bunkering. These are complementary approaches: the lens of social harm supplements and nuances the tools of traditional criminological theory. Together they provide a wider field of view, which not only encompasses individual culpability and state definitions of crime, but also emphasises the role of global social and economic structures that obstruct 'the fulfilment of fundamental needs' (Tifft \& Sullivan 2001, p. 191) — and thus produce harm. These structures include entrenched corruption and inadequate public service provision (Koos \& Pierskalla 2016). A social harm perspective also highlights the tunnel vision inherent in the 'language of crime' (Copson 2018, p. 49). Discourse around oil bunkering often adopts the terminology of theft. This language distracts from and disavows the claims of ownership that many Delta Nigerians lay to the land's natural resources. 
Proponents of a social harm perspective criticise criminology as bound to state-sanctioned notions of crime. For Pemberton (2004), criminal law is underpinned by the idea of individual culpability. Hillyard and Tombs (2017) similarly argue that, even where critical criminology scrutinises state definitions of crime, its framework still rests on an extant body of criminal law. Specifically, a preoccupation with the 'guilty mind', mens rea, shapes the individualistic basis of bourgeois law, hindering the attribution of criminal liability to collective entities or corporations (ibid., p. 289, 287). More broadly, individualistic theories are limited in their capacity to apportion responsibility. Robert Agnew's General Strain Theory (GST) is one such individualistic criminological approach. GST describes entrapment in aversive conditions and resultant 'goal blockage' (that is, the non-fulfilment of positively valued objectives). Goal blockage is, in turn, a driver for criminal activity (Agnew 2012, p. 33). Applied to oil bunkering, GST is illuminating in some respects - but ultimately it offers an incomplete picture.

Naanen $(2019$, p. 702,705$)$, who conducted a year-long qualitative field investigation in the Niger Delta, argues that approximately $20 \%$ of bunkerers are young, unemployed, impoverished Niger Delta residents, who cannot afford school fees or hospital bills. GST, in calling attention to harsh socio-economic conditions, can contextualise oil bunkering as the logical exploitation of market opportunity (ibid): bunkered oil can be refined as fuel for local use (even with basic equipment) and then peddled on the street, thus generating income (Katsouris \& Sayne 2013). Crucially, GST is not tied to social class and so embraces the range of socio-economic backgrounds that characterise oil bunkerers. Naanen estimates that the remaining $80 \%$ of bunkerers are affluent and well-connected oil barons, who use their wealth and social capital to vanish shiploads of oil into international waters (Naanen 2019, p. 702, 705). Ultimately, however, Agnew's (2012) emphasis is on life history of the individual. Whilst GST can elucidate certain individual drivers like goal blockage, it also isolates oil bunkering from an important causative context of entrenched socio-economic norms.

Elsewhere, critical criminology has sought to incorporate the structural into its analysis of crime. Green and Ward's (2017, p. 446) concept of corruption - 'the illegitimate use of state agencies' powers over the allocation of resources' - as a kind of 'vicious circle' is a useful analogy for affluent and well-connected oil bunkerers. Where corruption is already the norm, offering a bribe holds a promising chance of success with a low risk of punishment (ibid.). Illegal 
bunkering of Nigerian crude oil likely began in the late 1970s or early 1980s. Nigeria was under military rule and high-ranking officers began misappropriating oil both to cultivate political stability and to enrich themselves (Katsouris \& Sayne 2013). The state-run Nigerian National Petroleum Company (NNPC) is now seen as 'one of the most politicized and compromised institutions of any oil-producing nation.' (ibid., p. 1). Crucially, the complicity of high-ranking state officials enables illegally extracted Nigerian oil to be absorbed into various countries in Latin America, Asia, and Eastern Europe (Baumüller et al. 2011; Katsouris \& Sayne 2013). Foreign banks store and launder the earnings of illicit oil networks: banks in the United States, the United Kingdom, Switzerland, Dubai, India and Singapore serve as hotspots for potential money laundering (Katsouris \& Sayne 2013). Legitimate refiners may also unwittingly purchase and process stolen crude (ibid.). In essence, bunkered oil is a player in the global market. By 'fencing' both the illicit funds and the bunkered commodity through global, state and interstate institutions, the corruption process successfully raises itself to the global stage (and suborns both witting and unwitting accomplices).

Green and Ward's (2017) 'vicious circle' concept does identify the recurrent and selfperpetuating nature of state-level corruption - but it locates such corruption within a wider context of state crime as 'organisational deviance, by state agencies [...], which violates human rights' (p. 439; emphasis original). That is to say, Green and Ward's (2017) analogy posits a singular, direct connection between perpetrator (state) and victim (state subject), and so fails to capture the self-renewing, circular and symbiotic link between the normalised behaviour of Nigeria's Government and the suffering of its people. By contrast, a social harm perspective captures harm - specifically, interference with 'the fulfilment of fundamental needs' (Tifft \& Sullivan 2001, p. 191) - more widely, as an ongoing process, rather than as a pattern of discrete events. Tombs and Hillyard (2017) concur: such denial of need fulfilment is a form of structural violence, propagated through economic and social organisation.

In this regard, Nigeria's weak institutions and oil infrastructure are important (Koos \& Pierskalla 2016). Oil revenue vastly outstrips the revenue generated by income tax, so that Nigeria has a political economy that is defined not by the needs of the Nigerian people, but by oil rents (ibid.). Moreover, the benefits of oil production are unequally distributed; a culture of corruption to the highest level is connected to rampant poverty and unemployment (ibid.). Le Billon (2005, 
p. 12, 24) links such corruption to discretionary control over substantial oil rents and describes a 'resource curse': although Nigeria has produced more than US\$350 billion-worth of oil over the past thirty years, the proportion of Nigerians who survive on less than US\$1 per day has increased from $36 \%$ to $70 \%$. Meanwhile, during his four-year rule of Nigeria, General Sani Abacha reportedly embezzled roughly US\$2.2 billion (ibid., p. 12). In essence, the economic conditions that may entice Delta inhabitants to oil bunkering are rooted in government activity within and around the oil industry. Behind the high oil rents that feed government corruption lies the reliance of developed and developing countries all over the world on oil as a source of energy. This reliance, in turn, hands enormous heft to the corporate oil sector (Allen 2012), including companies like Eni and Shell - power that has not been exercised to the advantage of the Nigerian people.

Together, government corruption and indifference to the needs of its people have produced weak public services, leaving whole populations vulnerable to further harm (Green \& Ward 2017). Fuel shortages and blackouts occur frequently in Nigeria (Koos \& Pierskalla 2016). Inadequate management of oil spills (which are caused by both the legal oil industry and illicit bunkering) has seen depletion of biodiversity - and so the destruction of traditional livelihoods based on fishing and agriculture (Allen 2013; UNEP 2011). In their study of corporate social responsibility initiatives in Nigeria, Uduji, Okolo-Obasi, and Asongu (2019) link such decline in traditional livelihoods (and the resulting high rates of unemployment) to the prevalence of human trafficking in the Niger Delta region. Unemployment and poverty leave individuals vulnerable to trafficking both within and beyond Nigeria, with the incidence in Nigeria's oil producing regions among the highest in the country (ibid.). Organised, transnational networks traffic Nigerian children and young people primarily for prostitution, pornography, domestic servitude, street trading, armed conflict, and ritual killings (ibid.; Ogunniran 2017). This toxic knock-on effect of oil bunkering extends tentacles far into the wider world: the principal trafficking destinations include Gabon, Niger, Cameroon, Benin, Italy, Spain, and Saudi Arabia (Uduji, Okolo-Obasi \& Asongu 2019; Ogunniran 2017).

There are also direct toxic effects at home. Exposure to crude, through oil spills, is carcinogenic, causes respiratory and other illnesses, and has resulted in a reduction in household food security of $60 \%$ - as assessed using the Cornell-Radimer scale (Ordinioha \& Brisibe 2013, pp. 12-13). Under Nigeria's Oil Pipeline Act (1990), oil spills not attributable to the legal industry 
do not attract compensation (including 'material relief' and medical care) for suffering populations in areas affected by bunkering (ibid., p. 14). This speaks to the kind of 'moral indifference' that, according to Pemberton (2004, p. 82), underpins the political elite's perpetuation of its subjects' suffering. Unlike the tools of traditional criminology, therefore, a social harm perspective can capture the denial of the fulfilment of human needs as a multidirectional web of interactions that are continuously made, remade, and reinforced.

Finally, a social harm perspective can help understand how 'the language of crime' operates (Copson 2018, p. 49). Authors, including Katsouris and Sayne (2013, iii, iv), use the vocabulary of "theft" and "steal[ing]" to refer to oil bunkering. This discourse draws on the Nigerian state's categorisation of bunkering as illegal. Whilst its illicit status is a fact, that discourse of illegality eclipses - and even disavows - alternative narratives: Delta Nigerians may see oil bunkering and artisanal refining as a legitimate economic activity for self-betterment (Naanen 2019). Equally, they may view themselves as marginalised and excluded from the prosperity bestowed by the legitimate oil economy (ibid.). Indeed, the Land Use Decree (1978) stripped local communities of any ownership rights to oil (Allen 2013). Bunkering may therefore be experienced as an act of reclamation, by the community, of the natural resources in its land (Naanen 2019). As Pemberton (2004) suggests, the language of crime can constrict the societal imaginary, so that only those harms delimited by the official criminal justice system are conceivable. Such language, in turn, reaffirms that system's 'moral hierarchy', whereby intentional acts are punished over moral 'indifference' (ibid., p. 82). Effectively, the language of crime is only a reliable source of information about itself. In this case, the validity of the language of theft both relies on and reinforces interpretations of ownership as resting with the Nigerian Government, as well as with the interests to whom that Government grants extraction rights.

Further research might consider, in depth, the network of international actors that enables bunkered oil to travel overseas; environmental degradation in the Delta; insurgent violence; and the relationship between licit multi-national oil corporations, operating in Nigeria, and illicit oil bunkering. Overall, a social harm perspective can enrich traditional criminological approaches by capturing the role of social and economic structures in the perpetuation of suffering and harm, an ongoing process that may be legitimated by 'the language of crime' (Copson 2018, p. 49). In the case of Nigeria, this conceptual alignment may be a necessary key in any attempts to unlock and 
resolve a deep malaise, so institutionalised that it has produced a vicious symbiosis between harmer and harmed.

\section{References}

Agnew, R 2012, 'Reflection on “A Revised Strain Theory of Delinquency”', Social Forces, vol. 91, no. 1, pp. 33-38, DOI 10.1093/sf/sos117.

Allen, F 2012, 'The Enemy Within: Oil in the Niger Delta', World Policy Journal, vol. 29, no. 4, pp. 46-53, DOI 10.1177/0740277512470928.

Baumüller, H, Donnelly, E, Vines, A \& Weimer, M 2011, 'The Effects of Oil Companies' Activities on the Environment, Health and Development in Sub-Saharan Africa', European Parliament Policy Department, viewed 15 October 2019, $<$ www.chathamhouse.org/sites/default/files/0811ep_report_0.pdf $>$.

Burgis, T 2015, The Looting Machine: Warlords, Tycoons, Smugglers and the Systematic Theft of Africa's Wealth, William Collins, London.

Copson, L 2018, 'Beyond "Criminology vs. Zemiology": Reconciling Crime with Social Harm' in A Boukli \& J Kotzé (eds.) Zemiology: Reconnecting Crime and Social Harm. Springer International Publishing, Cham, pp. 33-56.

Hillyard, P \& Tombs, S 2017, 'Social Harm and Zemiology' in A Liebling \& S Maruna (eds.) The Oxford Handbook of Criminology. Oxford University Press, Oxford, pp. 284-305.

Katsouris, C \& Sayne, A 2013, 'Nigeria's Criminal Crude: International Options to Combat the Export of Stolen Oil', Chatham House, viewed 22 October 2019, $<$ www.chathamhouse.org/sites/default/files/public/Research/Africa/0913pr_nigeriaoil.pdf $\geq$.

Koos, C \& Pierskalla, J 2016, 'The Effects of Oil Production and Ethnic Representation on Violent Conflict in Nigeria: A Mixed-Methods Approach', Terrorism and Political Violence, vol. 28, no. 5, pp. 888-911, DOI 10.1080/09546553.2014.962021.

Le Billon, P 2005, 'The Resource Curse', The Adelphi Papers, vol. 45, no. 373, pp. 11-27, DOI $10.1080 / 05679320500129037$.

Naanen, B 2019, 'When Extractive Governance Fails: Oil Theft as Resistance in Nigeria', Extractive Industries \& Society, vol. 6, no. 3, pp. 702-710, DOI 10.1016/j.exis.2019.03.019. 
Ogguniran, I 2017, 'Forward Looking or Backward Stepping: Evaluating Child Protection from Sexual Exploitation in Nigeria', Journal of Human Trafficking, vol. 3, no. 3, pp. 167-181, DOI 10.1080/23322705.2016.1146519.

Ordinioha, B \& Brisibe, S 2013, 'The Human Health Implications of Crude Oil Spills in the Niger Delta, Nigeria: An Interpretation of Published Studies', Nigerian Medical Journal, vol. 54, no. 1, pp. 334-354, DOI 10.4103/0300-1652.108887.

Pemberton, S 2004, 'A Theory of Moral Indifference: Understanding the Production of Harm by Capitalist Society' in P Hillyard, C Pantazis, S Tombs \& D Gordon (eds.) Beyond Criminology: Taking Harm Seriously. Pluto Press, London/Ann Arbor, pp. 67-83.

Tifft, L \& Sullivan, D 2001, 'A Needs Based Social Harm Definition of Crime' in S Henry \& M Lanier (eds.) What is Crime? Controversies Over the Nature of Crime and What to do About it. Rowman \& Littlefield, Oxford.

Uduji, J, Okolo-Obasi, E \& Asongu, S 2019, 'Corporate Social Responsibility in Nigeria and Multinational Corporations in the Fight Against Human Trafficking in Oil-producing Communities', Local Environment, vol. 24, no. 12, pp. 1097-1118, DOI $10.2139 /$ ssrn.3470614. 